\title{
ACADEMICS AND THE SUPREME COURT
}

\author{
Justice Susan Glazebrook*
}

Richard Posner laments what he sees as an unfortunate gulf between academia and the courts. To assess whether there is such a gulf in New Zealand, this address analyses the role of academics and judges. It concludes that academics provide valuable insights and assistance to the courts but that their role is much wider, being at its broadest the advancement of knowledge. By contrast, the primary role of judges at all levels is to decide the case in front of them according to law. This means that academics and the judiciary are engaged in different pursuits and, while the roles may converge at times, ultimately the differences must be respected. But there can and should be constructive dialogue. In this regard, the address discusses three areas where the New Zealand Supreme Court has received criticism from academics.

When I was asked to speak at this conference, it was suggested that I might like to talk about the relationship between academics and the judiciary in light of Judge Richard Posner's recent book Divergent Paths: the Academy and the Judiciary. ${ }^{1}$ That book does live up to its title in that the Judge chastises academics for their part in what he sees is an inappropriate gulf between academics and the judiciary. Judges are of course not spared, but the thesis of the book seems to be that academics should do their bit to fix the problems of the judiciary. He does not think the judiciary will heal itself any time soon. ${ }^{2}$

So let me consider whether there is a gulf between the judiciary and academics and, if so, what should be done about it. I speak in the New Zealand context as I would not be so bold as to try and

* DNZM, Judge of the New Zealand Supreme Court. This is an expanded version of an oral address given at the Australasian Law Teachers Association (ALTA) 2016 Conference "Advancing Better Government, Sustainable Economies, Vibrant Communities: Law's Role?" (Wellington, 8 July 2016). I am grateful to my clerk, Josie Beverwijk, for her assistance with this article.

1 Richard A Posner Divergent Paths: The Academy and the Judiciary (Harvard University Press, Cambridge (MA), 2016).

2 Posner suggests collaboration between judges and law professors on studies of the judiciary as one method of fixing the problems that he identifies: at 286-291. 
speak for my Australian colleagues. ${ }^{3}$ But before we can talk of any gulf, we need first to analyse the role of law teachers in relation to the judiciary and then talk about the role of the courts. ${ }^{4}$

Judge Posner discusses a number of roles for academics. First, he points out that law schools teach future judges and that they also taught the current batch. ${ }^{5}$ That was quite comforting to read for it means that in a way our mistakes can be seen as down to our law teachers, at least in inception, although I grant that we may have learned bad habits since we were released from the yokes of law school. I must also acknowledge, at least as far as I am concerned, that in those less competitive times, a number of us might have been slightly less attentive at law school than we should have been.

The next role that Judge Posner identifies is the supply of law clerks. Here I pause to indicate that our law clerks do not write our judgments, unlike it appears for many of the federal judges in the United States. ${ }^{6}$ Our clerks do, however, assist with guided research tasks related to judgments and also with papers that we write. ${ }^{7}$ They are particularly valuable in those roles, being recent graduates with insight into the latest legal thinking. For myself, in my time as a judge I have had excellent law clerks who are a credit to the institutions that have taught them.

The third role identified is the education of the lawyers who appear in front of the courts. In many cases, those same law teachers also provide continuing legal education for lawyers. While there are excellent counsel who appear before the New Zealand courts, some are not. But I will not try to lay the failings of counsel at your door. I think they have to take responsibility for themselves. However, I do have to congratulate the law schools on the current emphasis on teaching your students practical as well as academic skills. I have had the privilege of judging a number of moots over the years and some of your students would give many of the more experienced and world weary counsel a good run for their money. ${ }^{8}$

3 For an Australian perspective, see Robert French, Chief Justice of Australia "Judges and Academics Dialogue of the Hard of Hearing" (Inaugural Patron's Lecture at the Australian Academy of Law, Sydney, 30 October 2012). For an English perspective, see Lord Neuberger, Master of the Rolls "Judges and Professors - Ships Passing in the Night?" (Hamburg Lecture, Max Planck Institute, Hamburg, 9 July 2012).

4 As Kenneth Ripple notes, the appropriate role of a scholar at least partially depends on the view of the appropriate role of the judge: Kenneth Ripple "The Judge and the Academic Community" (1989) 50 Ohio St LJ 1237 at 1240 .

5 For his discussion on law schools, see Posner, above n 1, at 298-344.

6 See Judge Posner's comments on this: at 15 and 28.

7 For more on the role of clerks in the Supreme Court, see Max Harris "The Role of a Judge's Clerk at the Supreme Court of New Zealand: A 'Worm's Eye View'" in Andrew Stockley and Michael Littlewood (eds) The New Zealand Supreme Court - the First Ten Years (LexisNexis, Wellington, 2015) at ch 5.

8 See Lorne Sossin's revised speech "Law School as Social Innovation" (2017) 48 VUWLR 225 on the new approaches in academia in society. In his speech, Professor Sossin discusses the shift in legal education at universities such as the University of Ottawa and York University from an inward focus on legal doctrines to 
The final role identified by Judge Posner is providing informed critique. It is in this role in particular that Judge Posner considers there are failings. In his view academics are now providing less support to judges than in the past. He puts this down to increasing specialisation, and, perhaps in contradiction, the move for law schools to be more interdisciplinary. ${ }^{9} \mathrm{He}$ is also none too keen on the concentration on theory and in particular constitutional theory. ${ }^{10} \mathrm{He}$ laments the increasing tendency of academics to write more for each other (perhaps as a function of funding and tenure issues) than for judges and lawyers. ${ }^{11}$ And he particularly laments the lack of scholarship analysing the behaviour and organisation of the judges themselves. ${ }^{12}$

For myself, I have always found academic articles and texts of great assistance, ${ }^{13}$ although I did hear second hand that a former clerk once referred to one of my judgments as "over-researched as usual". As an ex-academic, albeit not in law, old habits die hard. In my defence, one of the criticisms Judge Posner levels at the United States federal judiciary (whether fairly or not) is the lack of research effort put in by those judges. ${ }^{14}$

I find the criticism of judgments of the courts particularly helpful, even if accompanied by a period of judicial sulking if commentators do not see things my way. Seriously though, criticism is healthy and influential, ${ }^{15}$ especially if phrased politely. Commenting on particular decisions as they wend their way through the courts can also be helpful but it must be clear that the commentary is nonpartisan. There is now more of a tendency for academics to become involved in cases themselves in the sense of giving legal advice and even appearing. There is an issue with the impartiality of case

an outward focus on problem solving, community engagement and social innovation. A number of law schools in New Zealand have been involving students in community engagement projects, but not to the extent described by Professor Sossin. I applaud this initiative. While listening to Professor Sossin, it occurred to me that one of my enduring memories from law school was a short spell in a community law centre and I often refer back to that experience when thinking about the role of the legal profession and access to justice issues.

9 Posner, above $\mathrm{n} 1$, at 284

10 At 262

11 At 278 .

12 See for example at 262-263.

13 My personal view is supported by empirical research regarding the citation of authorities in substantive decisions of the Supreme Court, conducted in 2012, which shows that other judges of this Court share this view. In more than half of the cases reviewed, academic commentary was cited: Grant Hammond "Judges and Academics in New Zealand" (2013) 25 NZULR 681 at 695-697.

14 Posner, above n 1, at 252.

15 I agree with Professor Peter Birks that the function of the academic is "to analyse, criticise, sift, and synthesise, and thus to play back to the judges the meaning and direction of their own daily work, now conducted under ever increasing pressure": Peter Birks "The academic and the practitioner" (1998) 18 LS 377 at 399. 
commentary in such cases. ${ }^{16}$ Merely indicating that there has been some involvement is not really sufficient until well after the dust has settled and the matter can be reassessed outside of the pressures the adversarial process can put on even the most determinedly independent expert. ${ }^{17}$

I also enjoy the informal legal blogging (which is becoming so much more popular) and I pause here to say that "intelligent blogger" is not an oxymoron when looking at some of the best academic blogs. And some of them even attract at least some intelligent dialogue in the comments, which is no mean feat. ${ }^{18}$

So far I have been looking at academia in relation to the judiciary. That is all well and good but I think it a mistake for academia, even in law schools, to be so narrowly defined. At its broadest, the job of the academic is to advance knowledge, both in teaching and research. ${ }^{19}$ This means that it cannot be confined to what is useful to the profession or the judiciary. ${ }^{20}$

As I have mentioned, Judge Posner is not particularly keen on theoretical academics but I do not think one can really function in the profession without having a broader understanding of the nature of law. ${ }^{21}$ And that is especially important for students at the beginning of their careers. I do have some

16 Studies have shown that expert witnesses can suffer unconscious bias simply from being "part of the team": see for example BL Diamond "The fallacy of the impartial expert" (1959) 3 Arch Crim Psychodynamics 221; and Daniel C Murrie and others "Are Forensic Experts Biased By the Side That Retained Them?" (2013) 24 Psychol Sci 1889. The same must apply to counsel and advisers.

17 In my view, if academics do take briefs in such cases it should be on the basis that this should not compromise their academic freedom to comment on the case (once it is totally completed) in a manner that may be contrary to the position taken in the course of the proceedings.

18 One such example being the popular New Zealand blog Pundit, which attracts both contributions and comments from academics: <www.pundit.co.nz>.

19 See for example Stanley Fish Save the World on Your Own Time (Oxford University Press, Oxford, 2008) at 19. See also Allan Hutchinson "Doing the business: Judges, Academics and Intellectuals" (2010) 29 UQLJ 133 for another view of the differing roles of academics. Hutchinson distinguishes between traditional and critical legal intellectuals at 134: "Whereas traditional intellectuals see themselves as part of the same professional community as lawyers and judges, critical intellectuals align themselves with a broader and often different social context of allegiances. In short, traditional academics are members of the legal profession first and foremost: critical academics see their involvement with the legal community only as a necessary corollary to their more general identity as members of the professoriate."

20 In his speech, Sir Kenneth Keith pointed out that Parliament (no doubt with a lot of influence from the academics) also took this view of the role of universities in the 1960s statutes. See KJ Keith "The Academic Endeavour: 1956-2016-????" (2017) 48 VUWLR 251 at 254.

21 One of my regrets is not having done jurisprudence at law school and I congratulate those law schools where it is compulsory. 
sympathy for his criticism of the esoteric nature of some of the writing in the area, but am not as concerned as he is about length as long as there are clear summaries and headings. ${ }^{22}$

Not everyone is theoretical, however, and nor should they be. Some academics are more interested, and legitimately so, on the impact of law on society. So they want to take a more interdisciplinary approach. Others may only be interested in discussing what the law should be and persuading legislators and indeed the community to take their side. ${ }^{23}$ If the job of the academic is looked at in terms of the advancement of knowledge, that diversity of approach must be legitimate and necessary.

Just to give some flavour of the diversity of views on the aim of legal scholarship, in a 2002 Harvard Law Review issue, the editor in his introduction ${ }^{24}$ summarised the views of the authors: they ranged from Judge Posner's "importing the best techniques of modern scholarship from other academic fields into the practice of law", 25 through Professor Epstein's "determining the best legal rule for a given type of situation",26 Professor Rhode's "exploring how legal rules and legal institutions work in action"27 and Professor Torres' "developing the multiple deep social perspectives from which the law can be viewed". ${ }^{28}$ There was also a quote about the theatre of law which I confess to not fully understanding and which incidentally did not seem very related to the article referred to, so I left it out.

Now let us compare all that with the role of judges. To boil that down to its essentials, the role of the courts is to decide and adjudicate on the cases that come before them. And that applies to every level of court, even for final courts. It is true that most final courts only take cases of general or public

22 Posner, above $\mathrm{n} \mathrm{1,} \mathrm{at} \mathrm{278.} \mathrm{Posner} \mathrm{critiques} \mathrm{academic} \mathrm{writing} \mathrm{for} \mathrm{being} \mathrm{too} \mathrm{abstract,} \mathrm{too} \mathrm{dense} \mathrm{and} \mathrm{hidden} \mathrm{in}$ law reviews which are themselves too long

23 Judge Posner criticises legal academics who propose reform, saying that it is mostly unrealistic. However, he does acknowledge that some academic commentary has been clearly influential and helpful in shaping the law. One such example he gives is uniform codes: at 266-267 and 284. In New Zealand, a number of academics have been involved in Law Commission reports which have resulted in very successful "real world" legal reforms: see John Burrows "Academics and Law Reform" (2013) 25 NZULR 667.

24 Todd Rakoff "Introduction" (2002) 115 Harv L Rev 1278.

25 Richard Posner "Legal Scholarship Today" (2002) 115 Harv L Rev 1314.

26 Richard Epstein "Let the Fundamental Things Apply: Necessary and Contingent Truths in Legal Scholarship" (2002) 115 Harv L Rev 1288.

27 Deborah Rhode "Legal Scholarship" (2002) 115 Harv L Rev 1327.

28 Gerald Torres "Translation and Stories" (2002) 115 Harv L Rev 1362. 
importance but, once a case is before the court, it is still a matter of adjudicating on the particular case. $^{29}$

There are of course broader and more worthy definitions of the role of the judge and in some measure these are correct too, but they are subordinate in the sense that they are nevertheless aimed at better adjudication. As an example, former Chief Justice of Israel Aharon Barak wrote "that the role of the judge is to understand the purpose of law in society and to help the law achieve its purpose". ${ }^{30}$ I accept that this is important. In New Zealand, there has been a lot of work at first instance level which has this aim - for example the Rangatahi courts, which use the traditional values of tikanga Māori when dealing with young offenders. ${ }^{31}$ Other examples include the homeless special circumstances courts, ${ }^{32}$ the therapeutic drug courts, ${ }^{33}$ the domestic violence courts ${ }^{34}$ and the initiative for the involvement of the community in Porirua in the court processes. ${ }^{35}$

But there are some conceptions of the role of the judge that are just plain unachievable. For example, Ronald Dworkin's (admittedly idealised) hypothetical Judge Hercules, when faced with a new constitutional case: ${ }^{36}$

29 The New Zealand Supreme Court is not a constitutional court in the sense that New Zealand does not have a comprehensive, entrenched written constitution and the Court does not have the power to strike down legislation. I am not sure that, even if we did have such powers, my view of the role would differ. It is still a matter of adjudicating on the particular case.

30 Aharon Barak The Role of a Judge in a Democracy (Princeton University Press, Princeton, 2006) at 3.

31 See Heemi Taumaunu "Rangatahi Courts of Aotearoa New Zealand - an update" (2014) November Māori LR 1. For an overview of youth justice in New Zealand, see Andrew Becroft "Signed, Sealed - (but not yet fully) Delivered" (paper presented at the Healing Courts, Healing Plans, Healing People: International Indigenous Therapeutic Jurisprudence Conference, Vancouver, 2014)

32 See Alex Woodley "A Report on the Progress of Te Kooti o Timatanga Hou - The Court of New Beginnings" (Point Research Ltd, September 2012) available at <www.communityresearch.org.nz>. See generally K Thom and others "Evaluating problem-solving courts in New Zealand: a synopsis report" (Centre for Mental Health Research, 2013).

33 See Becroft, above n 31. See also Lisa Gregg and Alison Chetwin Formative Evaluation for the Alcohol and other Drug Treatment Court Pilot (Ministry of Justice, March 2014) available at <www.justice.govt.nz〉.

34 See Susan Glazebrook "Family Violence - domestic measures for a global problem" (paper based on an address given at the International Association of Women Judges' Asia-Pacific Regional Conference, Tagaytay City, 13 May 2015) at 12-13. See also Trish Knaggs and others The Waitakere and Manukau Family Violence Courts: An evaluation summary (Ministry of Justice, Research Report, August 2008) at 7.

35 See John Walker "The Porirua District Court and the Community - Working Together: Mainstreaming the Community Justice Model" (speech given at the Non-Adversarial Justice Conference, Melbourne, 7 May 2010).

36 This summary is given by Charles Fried "Scholars and Judges: Reason and Power" (1999) 23 Harv J L \& Pub Poly 807 at $810-811$. 
... surveys the whole of the relevant legal universe to determine how it fits with past decisions, the applicable texts, the principles, explicit and implicit in those decisions and the general and political moral theory of constitutional law in which those decisions and principles are embedded.

I am sure this would resonate with many of our District Court judges at the end of a long criminal list dealing with minor criminal matters or with members of our very busy intermediate Court of Appeal. Frankly, it does not resonate all that well even in my Court, where there are fewer cases but still time constraints. There might also legitimately be some criticism of over researching if we approached every decision as Judge Hercules would. ${ }^{37}$

That perhaps illustrates what might be seen as the fundamental difference between academia and the judiciary. I am certainly not suggesting that academics, unlike it would appear Judge Hercules, have unlimited time for research. Of course they do not, what with teaching commitments and the pressures to publish, both reputational and fiscal. ${ }^{38}$ But it is the role of academics to take the broader view, ${ }^{39}$ unlike judges who are confined to deciding the case in front of them (and I will discuss that a bit more later specifically in relation to final courts).

Deciding the case means applying the law to the particular facts. ${ }^{40}$ In many (and perhaps even most) cases, decisions will turn on their facts in the sense that it is just a matter of applying settled law to the facts once these have been determined. So, the role of the judge in a lot of litigation is as fact finder on the evidence presented, rather than researcher. This to a degree applies in New Zealand to appellate courts as well as we are perhaps more open than in some other jurisdictions to reviewing the factual findings of the trial courts. ${ }^{41}$

All this means that academics and the judiciary are really engaged in different pursuits, however much their activities may converge and however much they may work at times in similar ways from

37 Dworkin's concept of Judge Hercules was admittedly idealised and he (or she) presumably had infinite time and resources in which to make his (or her) decision. Judge Hercules was also embedded in Dworkin's concept of law: a liberal and democratic society in which the actions of judges reflect these values.

38 For more on this, see Margaret Wilson and ATH Smith "Fifty Years of Legal Education in New Zealand: 1963-2013: Where to From Here?" (2013) 25 NZULR 801 at 816-817. See further Petra Butler and Roderick Mulgan "Can Academic Freedom Survive Performance Based Research Funding?" (2013) 44 VUWLR 487; Diana Hicks "Performance-based university funding systems" (2012) 41 Research Policy 252; Bruce Curtis "The Performance Based Research Fund: research assessment and funding in New Zealand" (2008) 6 Globalisation, Societies and Education 179; and Michael Tilbury "Why Law Reviews?" (2003) 25 Syd LR 21 at $24-26$

39 This aligns with the view of ID Campbell in "Law \& the University" in Ernest Beaglehole (ed) The University \& the Community: Essays in honour of Thomas Alexander Hunter (Victoria University College, Wellington, 1946) 136 at 153, as cited by Keith, above n 20, at 257.

40 As Sir Kenneth noted: Keith, above n 20, at 257.

41 See for example Austin, Nichols \& Co Inc v Stichting Lodestar [2007] NZSC 103, [2008] 2 NZLR 141. 
the same materials. ${ }^{42}$ We can and should engage in dialogue with each other, ${ }^{43}$ but we must respect the differences and academics cannot expect judges to step out of their proper role and vice versa. ${ }^{44}$

Judges are, however, entitled to have a wish list of things they would like academics to research. Judge Posner has a particular perspective on this and thinks that academics should spend more time analysing the judiciary and individual judges empirically. ${ }^{45} \mathrm{I}$ did wonder about the wisdom of this in that it would necessarily involve mathematics and statistics and most lawyers (even academic ones) have a rather uneasy relationship with such subjects. But joking aside, I do think this would be valuable.

For myself, I would welcome more research on possible institutional bias in sentencing practices in New Zealand, whether based on race or other variables. There is already some useful work being done in this area. ${ }^{46}$ Also I, like Judge Posner, would be interested in more research on the process of

42 Fried, above n 36, at 810-811.

43 For more on this, see Alexandra Braun, who is of the view that in order to develop the law "both parties have to be prepared to listen to, and deal with, each other": Alexandra Braun "Professors and Judges in Italy: It Takes Two to Tango" (2006) 26 OJLS 665 at 665. See also Alexandra Braun "Judges and Academics: Features of a Partnership" in James Lee (ed) From House of Lords to Supreme Court: Judges, Jurists and the Process of Judging (Hart Publishing, Oxford, 2011) 227 at 227.

44 Neil Duxbury was of the view that judges and academics live in "two distinct legal worlds and are engaged in different enterprises": Neil Duxbury Jurists and judges: an essay on influence (Hart Publishing, Oxford, 2001) at 74. This is exemplified by Megarry VC, who on the bench disagreed with his position as an author, in Cordell v Second Clanfield Properties Ltd [1969] 2 Ch 9 at 16-17: "the process of authorship is entirely different from that of judicial decision. The author, no doubt, has the benefit of a broad and comprehensive survey of his chosen subject as a whole, together with a lengthy period of gestation, and intermittent opportunities for reconsideration. But he ... lacks the advantage of that impact and sharpening of focus which the detailed facts of a particular case bring to the judge. Above all, he has to form his ideas without the aid of the purifying ordeal of skilled argument on the specific facts of a contested case. Argued law is tough law." In my view, this demonstrates the sharpened focus of law in practice which by its nature is more narrow than the academic approach to law, as discussed above. In a New Zealand context, in Cossey v Bach [1992] 3 NZLR 612 (HC) at 626, Fisher J said: "Although Fisher on Matrimonial Property (2nd ed, 1984) at para 1.30 suggests otherwise, the customary indifference to the views of a living author apply with even more than usual force in that case." In Jones v Borrin [1989] 3 NZLR 227 (HC) at 253-254, he said, when referred to his work: "In isolation, that statement might be thought to provide some support for Mr Chambers' argument. One can only deplore the looseness of the language employed on that occasion by the unfortunate author."

45 Posner, above n 1, at 276. If judges are willing to be open to studies of this nature, I agree this can only strengthen the institution rather than threaten it.

46 Many readers may have seen the billboards around Wellington demonstrating the difference in outcomes for welfare fraud and tax evasion. Research by Dr Lisa Marriott showed that only 22 per cent of those found guilty of tax offences received a custodial sentence, while 60 per cent of those found guilty of welfare fraud were imprisoned: Victoria University of Wellington "Courts more lenient on white collar criminals" <www.victoria.ac.nz>. For more, see Lisa Marriott "The Construction of Crime: The Presumption of BlueCollar Guilt and White-Collar Innocence" (2017) 16 Social Policy and Society 237; and Lisa Marriott "An investigation of attitudes towards tax evasion and welfare fraud in New Zealand" (2017) 50 ANZJ Crim 123. 
decision making and particularly on ways of dealing with unconscious bias and instinctive reasoning flaws in judicial decision making. ${ }^{47}$ I would also be interested in more research that critically examines trial processes including the limits of the adversarial sacred cow. There is already some very valuable work being done on this, particularly as it relates to vulnerable witnesses. ${ }^{48}$

Others have other wish lists. For example, Sir Geoffrey Palmer thinks that academic lawyers, in New Zealand at least, devote too much time to the analysis of court decisions when they should pay more attention to the process of legislation making and to empirical research on its results. As he points out, these days it is from legislation that most judicial decisions spring. ${ }^{49}$ Sir Kenneth Keith, in his talk, commented that the current gap in academic writing on "maintaining or restoring good government" was a serious failure of responsibility. ${ }^{50}$

But academic independence means that all of these can only be wish lists. And that is as it should be. Knowledge can only be advanced through diversity of thinking and research.

So now finally turning to the advertised topic: academics and the Supreme Court. As you will know, the Supreme Court in New Zealand is a relatively young court, having not that long ago celebrated its tenth anniversary. And 10 years is really too short a period to discern trends, although there have been very good articles, books and conferences that have done their best. ${ }^{51}$

47 For more on this point, see C Guthrie, J Rachlinski and AJ Wistrich "Blinking on the Bench: How Judges Decide Cases" (2007) 93 Cornell L Rev 101; Reg Greycar "Gender, race, bias, and perspective: OR, how otherness colours your judgment" (2008) 15 Intl J Legal Prof 73; Fred Phillips The Modern Judiciary: Challenges, Stresses and Strains (Wildly, Simmonds and Hill, London, 2010) at ch 7; and Bronwyn Morrison Identifying and responding to bias in the criminal justice system: a review of international and New Zealand research (Ministry of Justice, 2009).

48 As an example, some of this work includes Emily Henderson and others "Child witnesses in the New Zealand criminal courts: A review of practice and implications for policy" (Institute of Public Policy, 2010); Yvette Tinsley and Elisabeth McDonald "Use of Alternative Ways of Giving Evidence by Vulnerable Witnesses: Current Proposals, Issues and Challenges" (2011) 42 VUWLR 705; and Acclaim Otago "Understanding the problem: an analysis of ACC appeals processes to identify barriers to access to justice for injured New Zealanders" (University of Otago Legal Issues Centre, July 2015).

49 Geoffrey Palmer "The Supreme Court of New Zealand after 10 years" [2016] NZ L Rev 86 at 116. Other examples include Lord Reed, who thinks there needs to be more on the contingent and creative nature of lawmaking, rather than the current doctrinal focus: see Lord Reed "Triremes and Steamships: Scholars, Judges and the Use of the Past" (The Scrymgeour Lecture, University of Dundee, 30 October 2015). Lord Rodger has also commented that academic work on the meaning of complicated statute and regulations is lacking: see Lord Rodger "Judges and Academics in the United Kingdom" (2010) 29 UQLJ 30 at 36-37.

50 Keith, above n 20, at 258.

51 See Andrew Stockley and Michael Littlewood (eds) The New Zealand Supreme Court - the First Ten Years (LexisNexis, Wellington, 2015); and Mary-Rose Russell and Matthew Barber (eds) The Supreme Court of New Zealand 2004-2013 (Thomson Reuters, Wellington, 2015). See also Trevor Shiels "Multiple Judgments and the New Zealand Supreme Court" (2015) 14 Otago LR 11; Palmer, above n 49; M Wilson "Further 
I will comment this morning on three areas where the Court has come in for criticism. I am confining myself to what can be called process issues rather than substance as it would not be appropriate for me to re-litigate the Court's decisions. The first criticism is not new in that it was also often levelled at the Court of Appeal when it was the de facto final court in New Zealand. ${ }^{52}$ The criticism is that the Supreme Court, when a case comes before it, does not take the opportunity to deal with the issues arising in a broader sense, either to clear up uncertainties in the law or to develop the law. ${ }^{53}$

There is a good reason for this and it relates back to the role of the courts as adjudicators. As has often been said, courts do not choose their controversies. ${ }^{54}$ They are also limited to the material (at least the factual material) that the parties choose to put before them. The courts are not of course

Supreme Court Statistics" (2012) 20 Wai L Rev 84; and M Henaghan "The Changes to Final Appeals in New Zealand Since the Creation of the New Zealand Supreme Court" (2011) 12 Otago LR 579.

52 Prior to the establishment of the Supreme Court, the Privy Council was the final court of New Zealand. However, the Court of Appeal was often viewed as the de facto final court in New Zealand: Bruce Harris "Judicial Activism and New Zealand's Appellate Courts" in Bruce Dickson (ed) Judicial Activism in Common Law Supreme Courts (Oxford University Press, Oxford, 2007) 273 at 278. During the period 1958-1996, less than 0.9 per cent of cases heard by the Court of Appeal were heard by the Privy Council on appeal: Peter Spiller New Zealand Court of Appeal 1958-1996: A History (Brookers, Wellington, 2002) at 359. There was a reluctance of the Privy Council to grant leave for criminal appeals. For example, in a survey of the years 1960, 1970, 1980, 1990, 2000 and 2007, only nine criminal appeals were granted leave to the Privy Council and only three of these were successful: Ivor Richardson "The Permanent Court of Appeal: Surveying the 50 Years" in Rick Bigwood (ed) The Permanent New Zealand Court of Appeal: Essays on the First 50 Years (Hart Publishing, Oxford, 2009) 297 at 318. Further, for civil cases, the cost of taking a case to the Privy Council could be prohibitive. The Privy Council respected the Court of Appeal's view of New Zealand conditions and also that the common law could develop differently based on the different conditions. This is exemplified in the case of Invercargill City Council v Hamlin [1996] 1 NZLR 513 (PC), where the Privy Council upheld a Court of Appeal decision which departed from the approach of England at that time, recognising that the Court of Appeal was entitled to depart from English law: at 519-520. For a comparison of the Supreme Court and the Privy Council, see Henaghan, above n 51.

53 See for example Rebecca Walsh "Takamore v Clarke: A Missed Opportunity to Recognise Tikanga Māori?" (2013) 19 Auckland U L Rev 246; Grant Hammond "The Court and the Executive" in Andrew Stockley and Michael Littlewood (eds) The New Zealand Supreme Court - the First Ten Years (LexisNexis, Wellington, 2015) 37 at 54; and James Farmer "A Barrister's Perspective" in Mary-Rose Russell and Matthew Barber (eds) The Supreme Court of New Zealand 2004-2013 (Thomson Reuters, Wellington, 2015) 61 at 89. At the Court of Appeal, see for example Joseph Williams "Lex Aotearoa: An Heroic Attempt to Map the Māori Dimension in Modern New Zealand Law" (The Harkness Henry Lecture, University of Waikato, 7 November 2013), commenting on Ngati Rangi Trust v Genesis Power Ltd [2009] NZCA 222, [2009] NZRMA 312; Harris, above n 52, at 317-322; and James Farmer "The New Zealand Court of Appeal: Maintaining Quality after the Privy Council" in Rick Bigwood (ed) Legal Method in New Zealand (Butterworths, Wellington, 2001) 240 at 247, commenting on Attorney-General v E [2000] 3 NZLR 257 (CA).

54 Michael Kirby "Judicial Activism" (1997) 23 CLB 1224 at 1232. See also RP Austin "Academics, Practitioners and Judges" (address at the 50th Anniversary of the Sydney Law Review, Sydney, 20 November 2003). 
necessarily limited to the legal arguments put forward by counsel and will sometimes go outside them, subject to issues of natural justice. There may also be fairness issues if arguments are raised for the first time on appeal as the evidence may have been framed in a different way had they been raised earlier.

Inevitably, however, the arguments of counsel will be framed in terms of the particular interests of the parties in the particular case. ${ }^{55}$ And that is also true of the judges involved - their consideration of the law will be in the context of the particular facts before them. Going too far outside of the case to make more general statements about the law has the danger that the law as propounded will not work in other factual circumstances. ${ }^{56}$

As to the development of the law, there are limits on judges. The first comes from what can be seen as both the strengths and the limits of common law reasoning which, although allowing development of the law, does so incrementally and with a clear view on past precedent. ${ }^{57}$ Judges are also limited in the development of the law because of the pervasive nature of legislation which more and more defines the law in modern democracies, and this is very much the case in New Zealand. ${ }^{58}$ There, the judge's role is an interpretative one and, however creative a judge may want to be (and

55 As Judith Kaye, former Chief Judge of the New York Court of Appeals, has said: "Although it is the function of a state's highest court to develop, fashion, pronounce, settle, and declare broadly applicable principles in particular cases that will not only resolve litigants' disputes but also serve society generally, courts are formally guided only by the parties. Parties do not necessarily have in mind the sensible, incremental development of generally applicable principles of law; they often do not have that in mind at all": Judith Kaye "One Judge's View of Academic Law Review Writing" (1989) 39 J Leg Ed 313 at 319.

56 For more on the merits of so-called "judicial minimalism" and its impact on the development of the law, see Cass Sunstein One Case at a Time: Judicial Minimalism on the Supreme Court (Harvard University Press, Cambridge (MA), 1999).

57 This process has been described as "punctuated evolution": EW Thomas "So Called 'Judicial Activism' and the Ascendency of Judicial Constraints" (2005) 21 NZULR 685 at 705 . For more on this, see John Farrar "Reasoning by analogy in the law" (paper presented to the "Judicial Reasoning: Art or Science?" Conference for the National Judicial College of Australia, Australian National University College of Law and Australian Academy of Forensic Sciences, Canberra, 8-9 February 2009). See also Lord Goff "The Future of the Common Law" (1997) 46 ICLQ 745 at 753; and Rupert Cross and JW Harris Precedent in English Law (4th ed, Clarendon Press, Oxford, 1981) at 186-206. See also comments by Lord Reed, above n 49; Peter Blanchard "Judging and Law Reform" (speech given at Auckland University, Auckland, 5 March 2011); and Lord Rodger, above n 49, at 32.

58 For more on this, see Susan Glazebrook "Statutory Interpretation in the Supreme Court" (paper elaborating on an address given at the Parliamentary Counsel Office, Wellington, 4 September 2015) available at <www.courtsofnz.govt.nz>. This is also the case in Australia: see M McHugh "The Growth of Legislation and Litigation" (1995) 69 ALF 37; and Stephen Gageler "Statutory Interpretation and the Use of Overseas Jurisprudence" (speech given to the Banking and Financial Services Law Association Conference, Queenstown, 29 August 2016). 
most do not), there comes a point when it is not possible to claim that a decision is interpreting legislation rather than ignoring or rewriting it. ${ }^{59}$

The second criticism is that, for at least some of the judgments of the Supreme Court, the essential reasoning has been unclear because judges have chosen to write separately and it is impossible to determine whether the differing formulations of the reasons for judgment indicate substantive differences or merely semantic ones. ${ }^{60}$ This is very related to the third criticism, of multiple judgments generally.

It may be that, despite the rhetoric, academics are not quite so bothered about this as practitioners or the courts lower in the hierarchy are. Practitioners and the lower courts have to apply the law as stated by the Supreme Court and, if it is not clear what the Supreme Court has decided, then there are real difficulties for them. Academics, I suspect, glory in the ability to discuss the nuances between the judges because it gives them easy fodder and a good article that does not necessarily take a great deal of time.

I do, however, have sympathy with those who plead for unanimous judgments where possible. Where there is a unanimous judgment, the Court speaks with one voice and this makes it much easier for everyone to know what the law is. Also, writing separate judgments in isolation from one another, while it might keep the purity of a particular judge's thinking and focus, does not have the benefits of collegiality in the sense of having one's views tested, discussed with all of the judges and incorporated into one judgment. ${ }^{61}$

Where a unanimous judgment is not possible because, despite every effort, there are substantive (as against semantic) differences in reasoning, I think it important that judges always try to indicate clearly where they agree with the other judgments and where they do not. ${ }^{62}$ I also think it important,

59 Fried, above n 36, at 811. See also Blanchard, above n 57.

60 As an example, the case of Vector Gas Ltd v Bay of Plenty Energy Ltd [2010] NZSC 5, [2010] 2 NZLR 44 has been widely criticised on this front: see for example Jessica Palmer and Andrew Geddis "What was that thing you said? The NZ Supreme Court's vexing Vector Gas Decision" (2012) 31 UQLJ 287; Henaghan, above n 51, at 586-589; and David McLauchlan "Contract Interpretation in the Supreme Court - Easy Case, Hard Law?" (2010) 16 NZBLQ 229 at 265. For general criticism on this point, see Shiels, above n 51; MaryRose Russell and Matthew Barber "Empirical Analysis of Supreme Court Decisions" in Mary-Rose Russell and Matthew Barber (eds) The Supreme Court of New Zealand 2004-2013 (Thomson Reuters, Wellington, 2015) 1 at 27-28; Mary-Rose Russell "Introduction" Mary-Rose Russell and Matthew Barber (eds) The Supreme Court of New Zealand 2004-2013 (Thomson Reuters, Wellington, 2015) xliii at li; and Phillip Joseph "Public Law in the Supreme Court: The First Ten Years" in Andrew Stockley and Michael Littlewood (eds) The New Zealand Supreme Court - the First Ten Years (LexisNexis, Wellington, 2015) 109 at 112-113.

61 For more on this, see James Lee "A Defence of Concurring Speeches" [2009] Public Law 305. For a unique insight on the judicial decision making process, see Alan Paterson Final Judgment: The Last Law Lords and the Supreme Court (Hart Publishing, Oxford, 2013).

62 See for example Dotcom v United States of America [2014] NZSC 24, [2014] 1 NZLR 355. In this case, both William Young $\mathbf{J}$ and I set out clearly in the text of our judgments and in footnotes where we agreed or 
when writing a dissent, to keep it as focused as possible (although there will be times when the majority's factual analysis just does not suffice for the reasoning and so some doubling up may be necessary).

But there is a legitimate alternative viewpoint. Those holding that alternative view would argue that, as long as the result is clear, judges should not be constrained in setting out their own reasoning in their own way as that adds richness to the law. Striving for unanimous judgments can lead to inevitable compromises and mean that the parties do not get the benefit of every judge's full consideration of the case. They would argue that it is especially important in final courts that the diversity of analysis is outlined for the sake of transparency, for future development of the law and to ensure that decisions are not reduced to the lowest common denominator. ${ }^{63}$

The legitimacy of both viewpoints and the overriding principle of judicial independence, mean that we are unlikely to see the end of multiple judgments in New Zealand. Further, although my personal preference is to aim for unanimity, this is not always possible and it is unrealistic to expect that it will be. It is difficult enough to get agreement from a group of friends on where to go for dinner. It is unrealistic, especially in a final court, to expect complete agreement on every aspect of a judgment every time. In order for the case to come before the Court in the first place, it is likely that there will be complex questions of law, often novel (at least in the particular fact situation), and it is also likely that there has already been substantial disagreement in the courts below. In such cases, it should not come as a complete surprise that unanimity on all issues is not always possible.

So to conclude back where I started: academics and the judiciary. We do have different roles, but that does not mean that there is always a gulf between us. Judges and academics have a lot in common and I for one value the dialogue that we have both on paper and in seminars and conferences of this nature. I like to think that this dialogue enriches both our judgments and your academic work. However, ultimately, we are engaged in different pursuits and for different ends and we should not apologise if at times we have to agree to differ.

disagreed with the other judgments. See for example [202(d)], [213], [224] and n 249 per William Young J, and [264], [273], [275] and $\mathrm{n} 291$ per Glazebrook J.

63 See also the comments in Lee, above n 61; Andrew Stockley "The Role of the Supreme Court - A Comparative Perspective" in Andrew Stockley and Michael Littlewood (eds) The New Zealand Supreme Court - the First Ten Years (LexisNexis, Wellington, 2015) 21 at 31-34; Farmer, above n 53, at 243-244; Roderick Munday "Judicial Configurations: Permutations of the Court and Properties of Judgment" (2002) 61 CLJ 612; Michael Kirby "Judicial Dissent" (address delivered to the Law Students' Society, James Cook University, Cairns, 26 February 2005); and Cass Sunstein Why Societies Need Dissent (Harvard University Press, Cambridge (MA), 2003). 
